\title{
Detection of Histoplasma Capsulatum in Domestic Chicken Droppings in Olenguruone, Nakuru County
}

\section{Kemoi Edson Kipyegon}

ITROMID, Jomo Kenyatta University of Agriculture and Technology

(J.K.U.A.T) Nairobi, Kenya.

School of Science and Technology, University of Kabianga, Kericho, Kenya.

\section{Stanslaus Kiilu Musyoki}

School of Health Sciences, Kisii University, Kisii, Kenya

\section{Stephen Mwaura Kariuki}

ITROMID, Jomo Kenyatta University of Agriculture and Technology

(J.K.U.A.T) Nairobi, Kenya

Medical School, Department of Medical Laboratory Sciences, Mount Kenya

University, Eldoret, Kenya

doi: 10.19044/esj.2017.v13n15p119 URL:http://dx.doi.org/10.19044/esj.2017.v13n15p119

\begin{abstract}
Histoplasmosis is a serious community acquired fungal infection among immunocompetent and immunocompromised individuals. Chicken droppings were evaluated for the presence of Histoplasma capsulatum, by culturing in Blood agar, SABHI and SDA agar at $25^{\circ} \mathrm{C}$ and $37^{\circ} \mathrm{C}$. Exoantigen were used for confirmation. Two Histoplasma capsulatum were isolated in this study. The study found that Chicken droppings harbor Histoplasma species.
\end{abstract}

Keywords: Histoplasma Capsulatum, Chicken droppings, dimorphic fungus

\section{Introduction}

Histoplasma capsulatum is a level-three pathogenic fungi causing histoplasmosis (Wheat, 1991). The genus, Histoplasma consists of three variants namely; Histoplasma capsulatum var. duboissii, Histoplasma capsulatum var. capsulatum and Histoplasma capsulatum var. farciminosum. Variants duboissii and capsulatum infect mammals (Human beings included) and variant farciminosum cause infection in mice and horses (WHO, 2009). Histoplasma capsulatum causes a serious community acquired mycosis in immunosupressed individuals in endemic regions in some countries (Wheat, 1991). Isolation of Histoplasma species from the environment has been done mainly in soil enriched with birds and bats guano (Ruchel, 2008). Farmers in 
endemic regions are unaware of the health implications associated with coming into contact with bird or bat manure in either active or inactive poultry houses, (CDC, 1997, USAEHA, 1992, CDC, 1977). The risk of Histoplasmosis infections in the environment is difficult to assess since there are no specific, fast or cheap analytical methods for the detection of Histoplasma capsulatum. The main aim of this study was to assess the presence of Histoplasma capsulatum in chicken droppings.

\section{Sample collections}

From January 2012 to April 2012, a total of 84 Chicken droppings were collected from Poultry houses and roosting sites. Approximately 10 to $100 \mathrm{~g}$ of bat droppings was collected using a sterile plastic spoon, in a plastic bag and transported to the laboratory on the same day using cool boxes.

\section{Materials and methods}

Approximately a gram of the Chicken droppings were suspended and vortexed thoroughly in $5 \mathrm{ml}(0.5 \% \mathrm{w} / \mathrm{v})$ saponin. The debris was allowed to settle and the supernatant transferred to a fresh tube. The resulting suspension were centrifuged, and the pellet suspended in a final volume of $500 \mu \mathrm{l}$ sterile $\mathrm{NaCl}$. One hundred microlitres $(100 \mu \mathrm{l})$ of the suspension were plated in duplicates on Sabouraud agar BHI and SABHI agar in $25^{\circ} \mathrm{C}$ for mycelia form and $37^{\circ} \mathrm{C}$ for yeast form. Microscopic morphology of mycelium was determined by use of Lactophenol cotton blue stain, micro cultures in the slides and tube culture in Blood agar, Sabouraud and SABHI agar with Chloramphenical, Getamycin and cycloheximid (De Hoog and Guarro, 1996, Ajello et al., 1993). The conventional Exoantigen method for detectetion of $\mathrm{M}$ and $\mathrm{H}$ protein were used for immunoidentification of the Histoplasma capsulatum mycelia form and discriminating from other fungi. Exoantigens were obtained by duplicates of 5 to 7 days $H$. Capsulatum cultures grown in BHI broth. After thimerosal sterilization for 24hrs, Exoantigen were obtained from supernatant after concentration and probed by immunoblot against homologous rabbit anti-Histoplasma capsulatum.

\section{Results}

Two Histoplasma capsulatum were isolated and identified in this study. Characterizations of isolates were observed in mycelia phase by development of buff brown to white colonies in culture media incubated at $37^{\circ} \mathrm{C}$. Typical Histoplasma capsulatum microscopic morphology which show presence of pyriform microconidia, spherical tuberculate macroconidia (thick walled) with finger like projections and thin septate hyphae were observed in all isolates. Production of Exoantigen confirmed Histoplasma 
capsulatum, by presence of precipitin lines in double immunodiffusion assay by using human histoplasmosis immune serum.

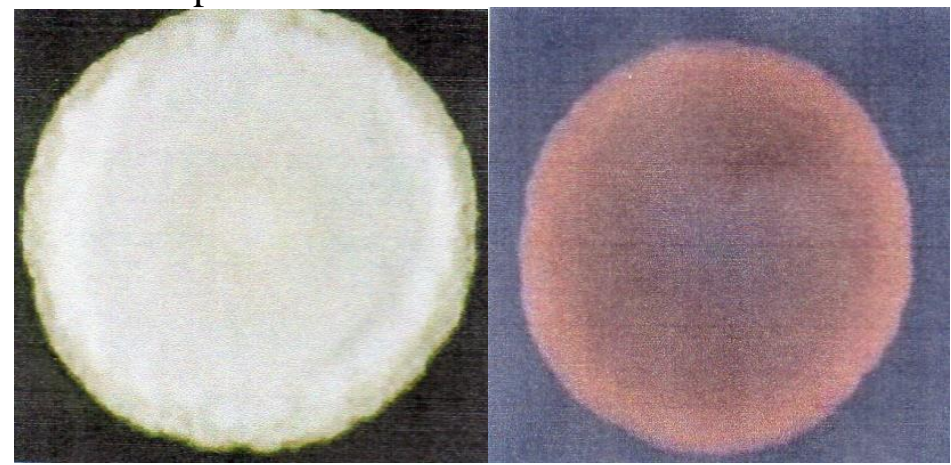

Fig 1: Histoplasma capsulatum colonies on SDA incubated at $37^{\circ} \mathrm{C}$ showing white-brown cottony colony with Brown yellow reverse.

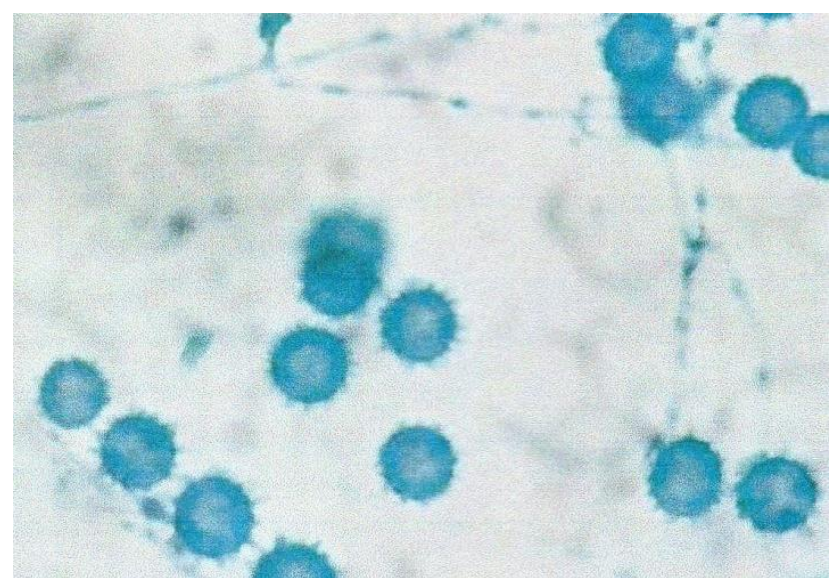

Fig 2: Lactophenol cotton blue mount of Histoplasma capsulatum showing numerous tuberculate macroconidia.

\section{Discussion}

Histoplasmosis has been reported in different countries from a variety of environments, which could be related to different Histoplasma strains isolated from different sources such as Soil, patients' samples and infected animal samples. This study isolated two Histoplasma capsulatum from chicken droppings which is normal, since isolation of Histoplasma capsulatum in nature is low, as reported by Mc Murray and Russell (1982). Histoplasmosis in Mexico and most of western countries has been associated with enclosed spaces where Bats roost (Taylor et al., 1994, Taylor et al., 1996, Taylor et al., 1997). In Kenya there is insufficient information that has been documented and that can link the disease and Histoplasma known habitats. In Africa, infections with Histoplasma capsulatum in HIV/AIDS patients has been reported by several authors in different countries (Amayo 
et al., 1993, Kakou et al., 1993, Bayes et al., 1996, Schoffer and Baur, 1998, Outarra et al., 1998). In West Africa, disseminated histoplasmosis has been reported in $3 \%$ of AIDS patients.

Bats are one type of vertebrates known to be infected with Histoplasma capsulatum. Most of Bats infected with this fungi exhibit a variety of diets and colonial habits: pollinivorous, hematophagous, piscivorous, insectivorous, nectarivorous and frugivorous. These suggest that the diet does not have any association with the occurrence of the infections in bat species (Kunz et al., 1988). The circumstances that foster the infections of Bats with Histoplasma capsulatum have not been reported. However, findings of this study shows close relationship between bats, characteristics of their roosting sites and parameters of the population that are involved in dispersion of spores and fungal growth hence bats are exposed to infection. In bat captured sites there is high risk of infections due to air currents produced by bats when flapping wings and animal movements, leading to dispersion of fungal spores. This way bats inhale the spores and get infected (Mc Murray and Russell, 1982, Carvajal, 1977). Also the physical conditions of caves, ceiling of the caves and guano deposits can influence the infection risk factor for bats and humans.

The present data from this study establish the close relationship between, Environmental conditions, characteristics of Chicken roosting sites with the risk of Histoplasma capsulatum infections. The fungus $H$. capsulatum grow well in soils with high nitrogen content enriched with chicken and bat droppings. The organism might carried on feet, wings and beaks of birds and infect roosting sites. Chicken have not been shown to present health risk for histoplasmosis because birds does not get infected with $H$. capsulatum, unlike Bats which they become infected with $H$. capsulatum. The high frequency of Histoplasma Capsulatum infections in different Birds and Bat species hence act as porters for fungal dispersion in the environment due to their migratory habits (Di Salvo et al., 1969). Other studies have reported isolation rate up to $35.2 \%$ (Gonzalez et al., 2014).

\section{References:}

1. Amayo D.E, Adam M.A. Riyat S.M. Toroitich K. (1993). Disseminated histoplasmosis in a patient with Acquired immunodeficiency syndrome: A case report. East. Afr. Med. J. 70:6162.

2. Ajello L.K, Kaufman I. Kaplan W. (1963). Laboratory manual for medical mycology Washington D.C. Public health services publication. 
3. Bayes B. Riberia M. Vaquero M. Romeu J. (1996). Histoplasmosis disseminate SIDA Aportacion de 4 cases. Med. Clin. Bare 106:700703.

4. Carvajal-Zamora R.J. (1977). Isolation of Histoplasma capsulatum from tissue of bats captured in Aguas Buenas , Buenos Caves, Puerto Rico. Mycopathologia 60: 167-69.

5. CDC (1977). Histoplasmosis control: decontamination of bird roosts, chicken houses and other point sources. Atlanta, GA: Centers for Disease Control and Prevention.

6. CDC (1997). Histoplasmosis: protecting workers at risk. DHHS (NIOSH) Publication No. 97-146.

7. De Hoog J.G. Guarro J. (1996). Atlas of clinical fungi, editors Reus, Spain.

8. Gonzalez A.G, Cecile A.D., Jose R.B., Christine D., Muriel P., Laura E.C.B., Haroon A., Sandra D., et al., (2014). Histoplasma capsulatum and pneumocystis species co-infection in wild bats from Argentina, French Guyana and Mexico. BMC Microbiol. 2014; 14:23. Doi: 10.1186/1471-2180-14-23.

9. Kakou A. Bissagnene E. Kra O. (1993). Etude retrospective de 24 de mycose profondes associees a infection a VIH Abidjan. $8^{\text {th }}$ International Conference on AIDS and STD in Africa, Marrakech (Abstract ThB 047).

10. Kunz T.H. (1988). Ecological and Behavioral methods for the study of bats, Washington D.C, Smithsonian institution's press.

11. Mc Murray N.D. Russell H.L. (1982). Contribution of bats to the maintenance of Histoplasma capsulatum in a cave. Am. J. Trop. Med. Hyg. 31:527-31.

12. Outarra L. Bedda Y.B, Niamkey K.E, Koffi K. Sanogo S. (1998). Histoplasmose a Histoplasma capsulatum: Apropos d un cas observe dans le sevice de medicine interne du CHU de Treichaville, Abidjan. Bull de la sot path01 de Exot. 91: 158-159.

13. Ruchel K.L. (2008). Outbreak of histoplasmosis among traveler returning from El salvader Pennsylvania and Virginia. MMWR mortal. Wkly. Rep. December, 19, 57:1349-53.

14. Schoffer H. Baur S. (1998). Papuloses exanthema bei systemicher histoplasmose under HIV-infection. Hautarzi. 49: 581-585.

15. Taylor M.L, Toriello C, Perez-Mejia A, Martinez M.A, Reyermontes M.N, Espinosh-Avila L, Chavez-Tapia C. (1994). Histoplasmosis in the state of Guerrero, Mexico: a biological approach. Rev. Mex. Microbiol. 10:49-53. 
16. Taylor M.L, Granados J, Toriello C. (1996). Biological and sociocultural approaches of histoplasmosis in the state of Guerrero Mexico. Myoses. 39:375-379.

17. Taylor M.L, Perez-Mejia A. Yamamoth-Furishe J.K, Granados J. (1997). Immunologic, genetic and social human risk factors associated to histoplasmosis; Studies in the state of Guerrero, Mexico. Mycopathologia 138:137-141.

18. USAEHA (1992). Managing health hazards associated with bird and bat excrement. Aberdeen Proving Ground, MD: U.S. Army Environmental Hygiene Agency, U.S. Army Environmental Hygiene Agency Technical Guide 142.

19. Wheat, L. J., P. Connolly-Stringfield, R. Blair, K. Connolly, T. Garringer, and B. P. Katz. 1991. Histoplasmosis relapses in patients with AIDS: detection using Histoplasma capsulatum variety capsulatum antigens levels. Ann. Intern. Med. 115:936-941.

20. World Health Organization (2009). Laboratory manual for diagnosis of fungal opportunistic infection in HIV/AIDS patients. Regional office for South-East Asia, Indraprastaha Estate, Mahatha Gandhi Marg. New Delhi 